\title{
VALUE CHAIN ANALYSIS ON GOAT PROCESSED PRODUCTS IN SURABAYA
}

\author{
Berto Mulia Wibawa*), Dewie Saktia Ardiantono*), and Ywang Nara Pragnya*1 \\ *) Business Management Departement, Sepuluh Nopember Institute of Technology \\ Jl. Raya ITS, Keputih, Sukolilo, Surabaya, East Java 60111
}

\begin{abstract}
One livestock commodity that has the potential to supply the people's need for the protein is goat, but the distribution of goat meat in Surabaya and its processed products can be said to be limited if compared to the superior commodities such as chicken and beef. This phenomenon may be caused by limited knowledge of value-added products, distribution of goat and goat processed products. The objective of this research was to establish a value chain recommendations of goat commodity. The qualitative method was used in this research and the data were collected from business actors in goat commodity through semi-structured face-to-face interviews and analyzed by value chain method analysis. The findings of this research show that there are 17 products that can increase goat commodity added value. Managerial implications are generally addressed to business players of Micro, Small, Medium Entreprises (MSMEs) and prospective business actors of processed goat products to be able to maximize the potential of goat livestock, which is aimed to improve product quality and added value of the product itself.
\end{abstract}

Keywords: goat, value chain analysis, processed food, MSME, commodity

\begin{abstract}
Abstrak: Salah satu komoditi ternak yang memiliki potensi dalam mencukupi kebutuhan masyarakat akan protein hewani adalah kambing, namun distribusi daging kambing dan produk olahannya di kota Surabaya terbatas jika dibandingkan dengan ayam dan sapi. Fenomena ini bisa disebabkan oleh terbatasnya pengetahuan akan nilai tambah serta distribusi produk olahan kambing itu sendiri. Penelitian ini bertujuan untuk menyusun rantai nilai rekomendasi dari komoditas kambing. Metode yang digunakan adalah kualitatif, responden adalah pelaku usaha pada komoditas kambing di Surabaya, data diambil melalui wawancara semi-structured dan berhadapan langsung, untuk kemudian dianalisis dengan metode value chain. Temuan penelitian ini yaitu terdapat temuan 17 produk olahan yang dapat meningkatkan nilai tambah komoditas kambing. Implikasi manajerial umumnya ditujukan kepada pelaku usaha skala UMKM atau industri dan calon pelaku usaha produk olahan kambing untuk dapat memaksimalkan potensi ternak kambing agar dapat meningkatkan mutu produk dan nilai tambah produk itu sendiri.
\end{abstract}

Kata kunci: kambing, analisis rantai nilai, produk olahan, UMKM, komoditas

\footnotetext{
${ }^{1}$ Corresponding author:

Email: ywangnara@gmail.com
} 


\section{INTRODUCTION}

One of the livestock commodities that has the potential to meet the community's need for animal protein is goat, and the advantage of goats is its high adaptability to various environmental conditions, high reproductive potential, bearing more than one offspring per birth (Mahmilia, 2007). The advantage of goat cattle is having the potency to support the fulfillment of animal protein needs which continue to increase along with the increasing number of Indonesian population.

Goat livestock has a fairly high population compared to other small ruminants (Table 1), as described by the population of small ruminants specifically for goats in East Java in 2015 i.e. 3,178,197 tails, while the population of the sheep was $1,282,910$ tails, and up to the year 2016, the goat and sheep population reached 3,279,732 tails and 1,370,878 tails respectively (Dinas Peternakan Jatim, 2016). Currently, the meat needs in Indonesia mainly come from: (a) poultry (broilers, male layers, native chickens and ducks), (b) cattle (beef cattle, dairy cows and buffalo), (c) pigs, and (d) goats and sheep. For the last few decades, product farming demands have increased, in tune with the population growth, community economic development, improvement in education levels, and lifestyle changes as a result of globalization and urbanization (Inounu, 2005). As a result, it can affect the level of production and consumption of each commodity that is relatively different in each country.
As consumption of goat meat in Indonesia is still very low compared to other developed countries such as European countries, and China, which consume 1,000 tons per year, and even consumption in Europe can reach twelve percent of world consumption of goat meat (AHDB, 2015). Consumption of goat in Indonesia has a tendency to only take place with sporadic spikes at certain time. The supply of goats in Indonesia currently still focuses on fulfilling the needs of sacrificial meat at Idul Adha, Aqiqah, and consumption of cut meat for culinary purposes. Meanwhile, the segment of other marketing in the form of processed products has not been well developed. Generally, daily meat consumption is pushed by beef and chicken meat. Consumption of goat meat by the community is still very low, at only around five percent.

This is supported by the data stating that the contribution of goat meat production to national meat production is 3.56 percent (Kementan, 2015). The low production of goat meat reflects the small level of consumption. If we look at the average of livestock commodities, goats are ranked sixth out of fifteen existing commodities. Goats had an average population of 3,068,778,667 within three years from 2013 to 2016, and, goats are among the top four consumption commodities of the Indonesian people, after chickens, ducks, cows. This shows that the goat commodity is not inferior to its consumption level compared to superior commodities such as chicken and beef.

Table 1. Population of Livestock in East Java

\begin{tabular}{lcccc}
\hline Types of Livestock & 2013 & 2014 & 2015 & 2016 \\
\hline Beef cattle & $3,949,097$ & $4,125,333$ & $4,267,325$ & $4,407,807$ \\
Diary cows & 237,673 & 245,246 & 255,947 & 265,002 \\
Buffalo & 28,118 & 28,507 & 27,792 & 27,304 \\
Goat & $\mathbf{2 , 9 3 7 , 9 8 0}$ & $\mathbf{3 , 0 9 0 , 1 5 9}$ & $\mathbf{3 , 1 7 8 , 1 9 7}$ & $\mathbf{3 , 2 7 9 , 7 3 2}$ \\
Sheep & $1,185,472$ & $1,221,755$ & $1,282,910$ & $1,370,878$ \\
Pig & 46,090 & 41,875 & 44,602 & 50,243 \\
Horse & 10,581 & 10,536 & 10,368 & 10,416 \\
Sails chicken & $33,806,963$ & $34,539,123$ & $35,728,314$ & $36,490,697$ \\
Laying Hens & $43,066,361$ & $41,156,842$ & $43,221,466$ & $45,880,658$ \\
Broilers & $52,288,601$ & $179,830,682$ & $194,064,874$ & $200,895,528$ \\
Duck & $4,213,379$ & $4,912,393$ & $4,983,776$ & $5,543,814$ \\
Gooey & 946,323 & $1,261,425$ & $1,354,956$ & $1,444,691$ \\
Rabbit & 326,776 & 331,476 & 265,865 & 344,597 \\
Pigeon & 734,378 & 978,134 & 986,371 & $1,176,582$ \\
Quail & $2,377,749$ & $2,770,908$ & $2,931,450$ & $3,281,998$ \\
\hline
\end{tabular}


The majority of world's poor rural and a significant proportion of poor urban keep livestock and use them in a variety of ways that extend far beyond income generation (Randolph et al. 2007). In addition, as in the market conditions, we cannot find any supply of goats in markets or in modern retail stores when compared to chicken or beef supply, as well as processed meat spread on the market. A lot of processed meat of cows and chickens exist in the market rather than processed goat meat. The supply of goats that is easily found or bought by consumers is raw meat compared to non-processed foods such as sausages, meatballs, and burgers.

Correspondingly, if the goat is reprocessed or used as a processed product, it is able to increase the product margin because it can provide more value rather than just fresh meat. Porter (1985) and Kaplinsky and Morris (2002) explain that an effective value chain is the key to competitive advantage that can produce value added for an industry. Product diversification with the development of value added will provide many choices for consumers and provide added value to products that have a higher selling value (Yusuf, 2007). Meanwhile, small ruminant animals such as goats, besides being meat producers also have the potential to produce high economic value skin, while specifically dairy goats besides producing milk can also produce meat after diafkir, and also produce skin, bones, horns and impurities that are very useful (Usmiati et al. 2011).

The potential growth of the goat meat market and the trend of product demand now begin to develop towards products that are relevant to consumer needs; therefore, the goat breeders and processing industries in East Java must adapt their products to the needs of their consumers. In line with that, the difficulty to find processed foods from goat products in Surabaya compared to middle-eastern countries showed that there was still no research and development available for goat processing which in fact can give added added value to the goat itself. Upstream and downstream business activities such as feed mills, nursery businesses, meat and milk processing, and compost processing are currently practically undeveloped; however, based on the industrial trees, the prospects are quite good to develop. The background of Surabaya was taken because based on the East Java Breeders Association, Surabaya will be designated as a city for goat exports in Indonesia, and according to Yusdja (2004), all districts in East Java have goats with a range of 40 to 140 thousand tails (except for the municipalities). Hence, the production of goats is relatively immovable from other areas except to municipalities such as Surabaya.

Various studies on value chains have been carried out such as studies conducted by Anam (2014) on the value chain of goat milk in a trading unit, by Endiyani (2014) and Dwikurnia (2014) on the value chain of red chili, and by Kresnawati (2013) on recommendations of milkfish processed products from value chain analysis; however, studies on goat commodity, especially processed goat products are not easy to find. From an analytical point of view, the value chain perspective is useful because (Kaplinsky and Readman, 2001; Wood, 2001) the focus moves from manufacturing only to the other activities involved in the supply of goods and services, including distribution and marketing. All these activities contribute to add value. Moreover, the ability to identify the activities providing higher returns along the value chain is a key to understand the global appropriation of the returns to production. Value chain research focuses on the nature of the relationships among the various actors involved in the chain and on their implications for development (Humphrey and Schmitz, 2002). Therefore, this research needs to be conducted to give a description of recommendations through value chain analysis of processed goats in Surabaya so that information on the processed goats can be available for the goat industry business players in making business decisions.

\section{METHODS}

The data used in this research included the primary and secondary data. The primary data were collected through interviews, questionnaire, and behavioral and non-behavioral observations (physical condition and physical process). The secondary data were obtained through the non-behavioral observations (record observations). The interviews (face to face) conducted had the characteristics of semi-structured interview.

In this study, sampling was done by snowball sampling for respondents from value chain, where the actors who were respondents in this study were: 1) The communities as consumers who have consumed goat meat and/or their preparations; 2) Processing businesses (Industry/SME) that process goats; 3) Retailers who sell goat products and/or their processed products and/ 
or collecting traders; and 4) Goat farmers. In this stage, there will be an existing mapping of the value chain in goat livestock commodity in Surabaya. According to ACIAR (2012), the stages in value chain mapping are as follows.

1. Core processes mapping in the value chain (Figure 1). The mapping of the core process was carried out to find out the processes that occured from the beginning to the consumption of the final product.

2. Mapping stakeholders involved and specific activities were carried out by stakeholders from the core process, and each specific activity of the stakeholders was explained.

3. Product flow mapping. At this stage, the product was identified at each stage of the process when the producer experienced a transformation from input, raw material, semi-finished materials to the final product, both domestic and export.

4. Knowledge mapping and information flow. The knowledge mapping phase was carried out with the aim to equalize the quality requirements in each of the relevant stakeholders whereas information mapping was conducted to find out the information flow that occured to the relevant stakeholders.
5. Mapping product volume, number of actors and number of jobs. Product volume mapping was related to product flow mapping where the purpose of this stage was to determine the size of the various channels contained in the value chain. In contrast, the mapping of actors and employment was carried out to determine the needs of the number of workers involved and employment that could be absorbed.

6. Mapping the geographical flow of the product or service. At this stage, the geographical flow of the product followed the mapped product flow where at this stage, the physical location or the location of each value chain process was identified.

7. Value mapping at the level in the value chain. At this stage, the value of money mapping contained in the chain was carried out. Value is something that can be measured in various ways. Parameters that were used in this stage were income, cost structure, profit and investment returns. However, there is a possibility that only price information can be known in this process.

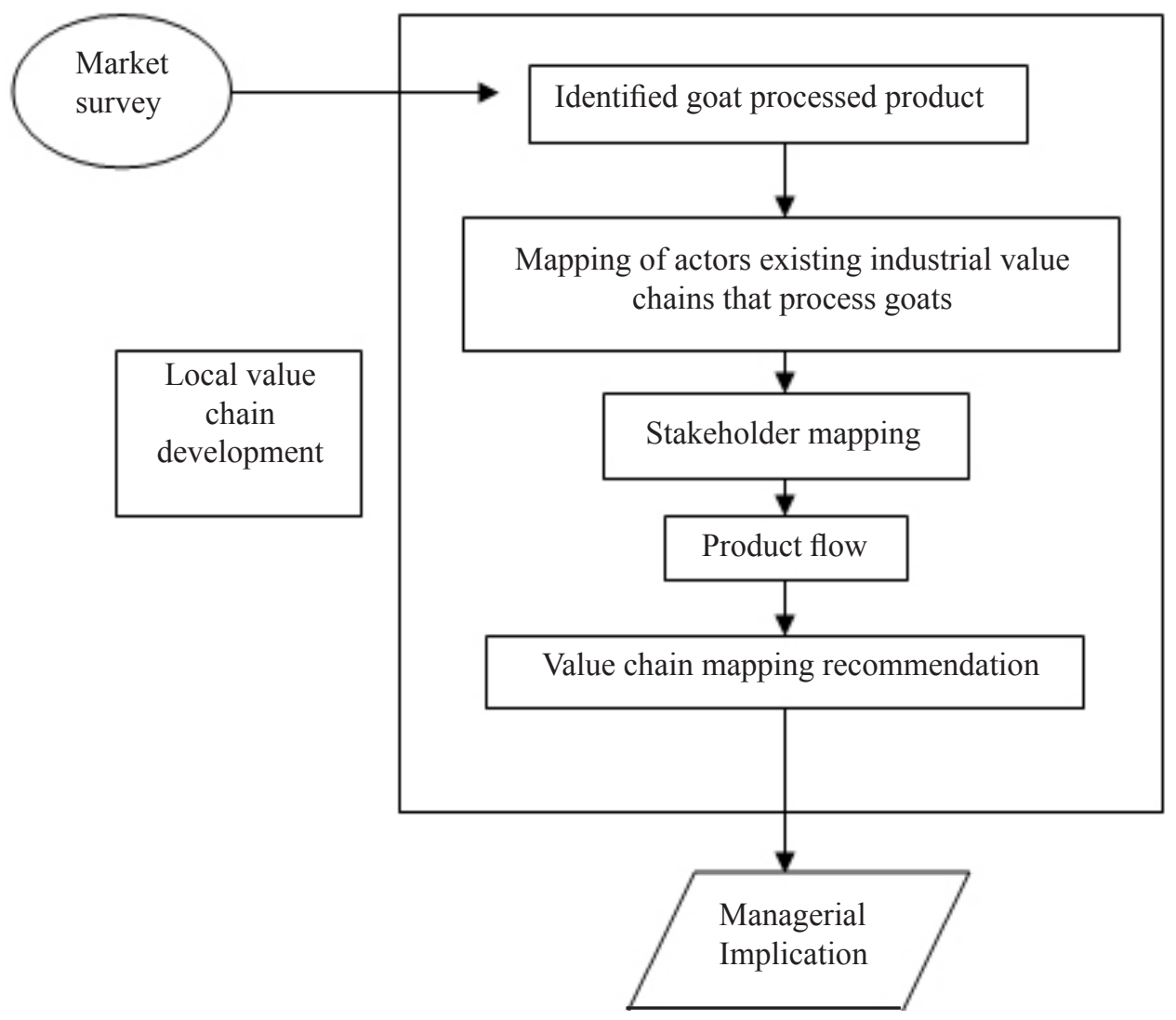

Figure 1. Research framework 
8. Mapping the relationship and linkages between stakeholders of the value chain. At this stage, mapping relationships and linkages of actors were categorized into three things: 8.1 Relationships that are formed directly in the market, in which the perpetrators conduct transactions including negotiating prices, volumes and etc.; 8.2 Relationships in networks that are intertwined, where this relationship occurs due to greater trust and interdependence, and 8.3 Horizontal integration, whereby the actor in this relationship has the same ownership (in legal terms); for example, a business group or cooperative.

9. Mapping business services. This stage was carried out to reduce the potential risk that came from the environment outside a value chain by creating a business service.

10.Mapping barriers and potential solutions. At this stage, identification of potential risks from the environment outside a value chain was carried out by creating a business service.

11.Making a value chain map matrix. This stage is a summary of various main information from the maps that have been made previously into a table. In value chain mapping, the data needed are the result of observations, interviews, questionnaires, and related statistical data.

\section{RESULTS}

This section discussed the result of collected data, and data collection was obtained from the primary data or the results of interviews with parties who play a direct role as observers and observations. The data for value chain analysis were taken from three sources who were actors in the goat commodity business residing in Surabaya. The value chain approach does not only look at the activities carried out by a single business but also include all good relations that move forward or backward, until the production raw material is finally connected to the end consumer (Kusumawardani 2012). In the value chain, processed goat products involved several actors (stakeholders) who contribute in providing their respective functions so that a product can have added value. Stakeholders are often expressed as parties, across actors, or parties related to an issue or plan. The identification of these processed products aims to support the selection stage of value chain analysis, because under existing conditions, processed products from goats are available in small quantities and distribution to end consumers is not like processed products in cattle or chickens. Process identification and selection of processed products that will be used as materials for value chain analysis are processed products that are most prioritized by respondents. In research on consumer preferences for previous processed goat products, the process of identification and selection of processed goat products in the value chain analysis was conducted. After being selected, the analysis will be used as observation material. The next step is the value chain mapping of selected processed products, where the purpose of this research is to find out and provide a value chain design on recommendations to the actors involved.

Based on previous research (Kresnawati, 2013), in determining value chain mapping, the important thing to do is to understand the activities that occur in each of the relevant actors. The following is part of the existing value chain mapping of goat commodity in Surabaya. Based on Figure 2, in the goat value chain, the core process starts from input, namely the provision of livestock germs. In the current condition of providing livestock breeds in the livestock industry from two parties i.e. farmers or breeders, the farmers usually buy seeds or seedlings from farmers with relatively cheap prices, and these seeds will later be kept in the cage or production to become goats ready for harvest, and this process is called fattening or fattening of livestock. from the results of the fattening, the goats ready for harvest are sent to the downstream to processing and marketing. Fattening generally occurs in almost all farms, after going through the process, the cattle are sent to slaughterhouses and to goat collectors in major cities in East Java, Central Java and West Java. The supplied goats will be processed into food or table food for consumption by consumers.

\section{Stakeholders involved in Goat Commodities}

The actors involved are consumers who consume goats, goat processing businesses, traders who sell processed goat products, and breeders or goat collectors. The explanation of Figure 3 in detail and the characteristics of each actor (stakeholder) are as follows: 


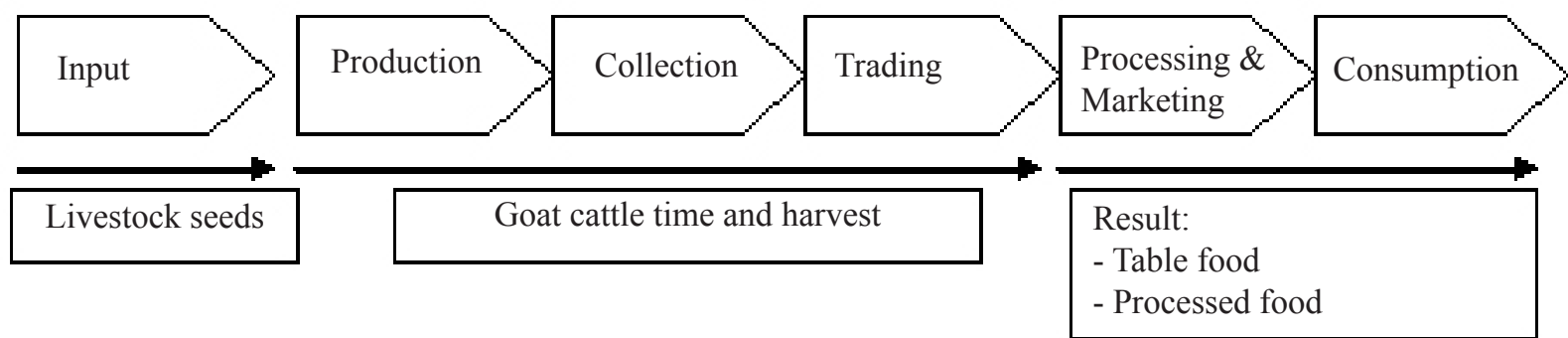

Figure 2. Goat's core processes

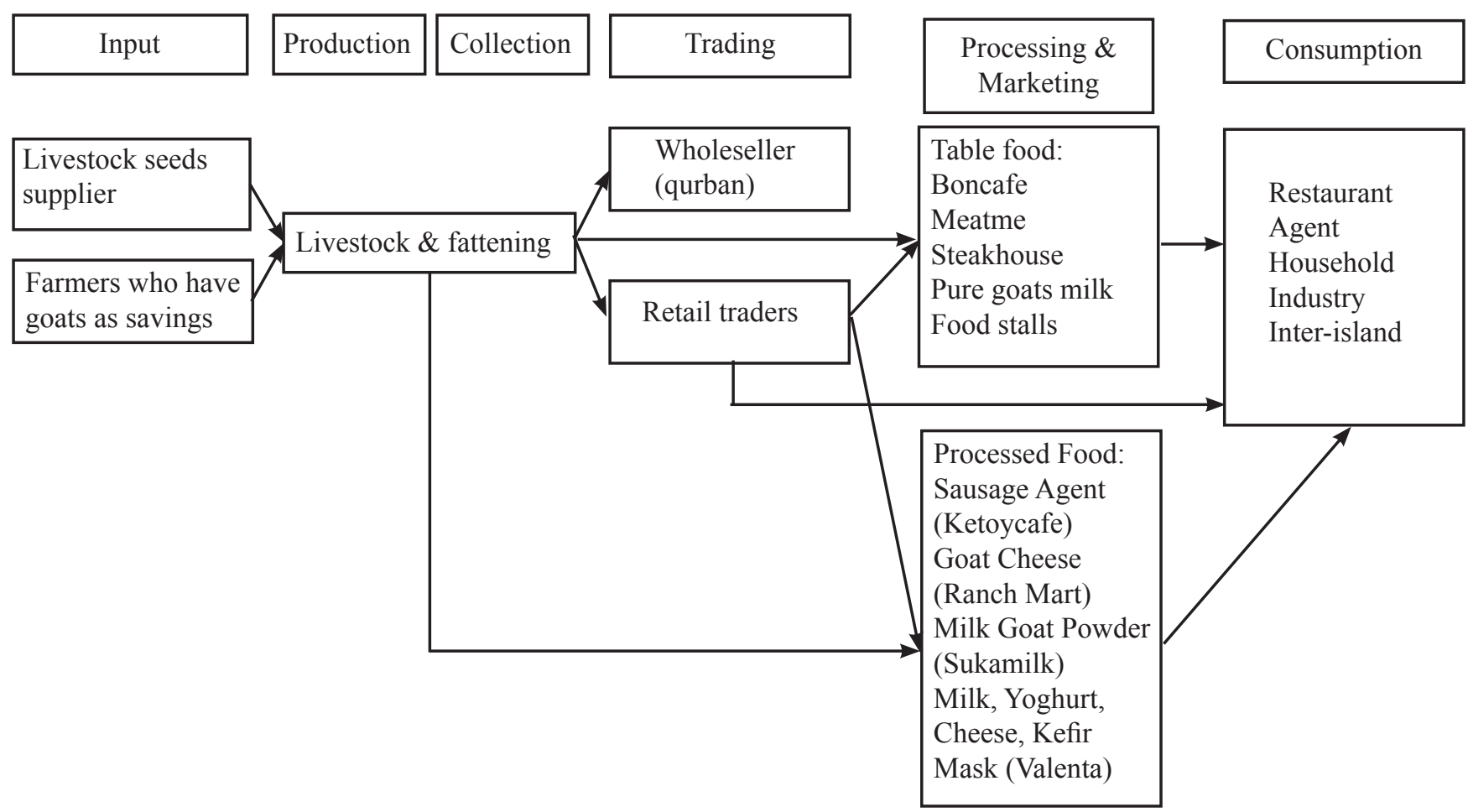

Figure 3. Stakeholder Mapping in Surabaya

\section{Consumers}

In the downstream category, there are stakeholders called consumers of the goats. Consumers that purchase goats and processed goat products consist of food stalls, households, aqiqoh places, people who are sick, people who are on a diet, expatriates, and people who are aware of health issues. From the initial preference, it is known that 47 percent of respondents still did not know that the goats had their own processed products. This confirms that the number of processed goat consumers or connoisseurs is generally small, compared with consumers of processed chicken or processed cows. This can be caused by the lack of processed goat products in the community, and the number of downstream products or products that are valuable added from processed goats is not as much as chicken and beef commodities.

\section{Processing Business}

Processing business is included in the core category if it is associated with the supply chain. The processing business in Surabaya is generally divided into two, namely, the table food and processed food. Table foods are generally food processing units such as satay, gule, goat steak, and some of the actors engaged goat processed food tables include restaurants like Boncafe, Steakhouse, Larazeta, Al hamra, and Meatme, and in addition to restaurants, processed goat products are commonly found at food stalls, depots, and street vendors, which sell satay and gule, and some can also be found in pure goat milk vendors in Surabaya, one of which is on Jalan Jemursari Surabaya. Then, the business of processing or processed food in Surabaya is very difficult to find, and one of the processing businesses in the processing industry in Surabaya and 
its surroundings for goat milk products is in the MSMEs sector, whereas for goat sausages there is no processing business unit either in the form of industry or MSMEs. In the sector MSMEs, goat milk processing unit sample source was taken based on information from farmers through interviews and observations. Valenta is one of the largest MMSMEs engaged in processing goat milk, and SEO valenta with the keyword "Surabaya goat milk" ranked first, and being one of the producers of Goat dairy products in Surabaya, Valenta has been running for more than ten years in this industry. Valenta not only produces products from goat milk but also other value-added products such as goat cheese, kefir, goat yogurt, masks, and even goat sinom which is still in the trial phase. Valenta takes the production from a self-owned farm managed by a partner and is located in Lumajang. From Lumajang, the goat milk products are processed into other value-added products to be marketed not only in Surabaya but also in large cities such as Jakarta, Bandung, Makassar, Balikpapan, and Samarinda. The value offered in this goat processing business unit is organic and taste of goat meat is good and does not smell.

\section{Retailers}

Through the value chain process, it can be seen that the actors involved in the goat commodity industry activities show that in the process of retailers who are divided into two, namely wholesalers such as qurban goat traders and retail traders who distribute to the processed industry. In addition, the position of retailers here plays a role in marketing their products, and actors in this sector, in processed dairy products and goat sausages, are known to be Valenta for goat milk and Ketoycafe for goat sausage. Valenta is a producer of goat milk processing, its business unit also still markets its products independently. In addition, it also has its own agents who usually sell processed products in addition to direct sales, and they rely on the exhibition of processed products from the government. Meanwhile, goat processed products are in the form of goat sausage in Surabaya and surrounding areas traded by Ketoycafe Surabaya, where the goat sausage is sold as one of its keto product lines. The goat sausage product itself is not produced in Surabaya, but in Jakarta, the center of Ketoycafe itself, and it will be distributed to big cities like Surabaya. The price of goat milk in stakes is $\mathrm{Rp}$. 40,000/liter for the surrounding Surabaya area, and for other areas, it is different. Moreover, the price of goat sausages is Rp. 95,000/ packs. After going through the actors, the products are sent directly into the hands of consumers in the downstream category for the value chain process.

\section{Collector Farmers}

It refers to farmers in Surabaya. Basically, the role and function of farmers and collectors is to receive livestock germs from farmers or suppliers of goat seedlings. Then, the fattening stage was carried out and distributed to table food processing food stalls such as satay, gule, tongseng. In addition to the markets in Surabaya, there is no goat going into the processing unit in Surabaya, because the processing industry does not exist yet. There are several actors who fall into this upstream category, namely, livestock seed suppliers, farmers who have goats and livestock and fattening, in the process after from upstream, the goats will then go to the core category in the supply chain.

\section{Goat Commodity Product Flow}

Product flow is obtained through interviews and observations. The yields of processed goat products for processed food are found in the City of Surabaya, processed by small and medium industries. Product flow mapping aims to find out the description of product changes ranging from inputs in the form of seeds to processed products consumed by consumers. In this processing process, generally the technology used is still in the technological stage at the SMEs level i.e. conventional technology, and the tools used at this level are limited to pasteurization machines, storage machines and extraction machines.

The market in Surabaya generally comes from farms outside Surabaya, such as in the horseshoe area, Lumajang, Probolinggo, Situbondo, Malang, from where the goats are sent to Surabaya to be processed into foods in general. As described in Figure 4, processing of goat products in Surabaya includes goat sausage, goat milk, goat cheese, goat yogurt, kefir, goat satay, gule kambing, goat steak, tengkleng kambing, tongseng kambing, and goat powder milk to be consumed by consumers, and the distribution of processed products for the processed food category is also difficult to find. When compared to countries like the Middle East, the results of diversification of goat processed products in Indonesia can be said to be little compared to them in the Middle East. 


\section{Recommended Value Chain Mapping of Goat Processed Products}

The current condition requires industry players from upstream such as farmers, to downstream like traders to be able to increase the added value of goat processed products, whether they are table food or processed food.

Based on interviews conducted, there are a large number of processed food table goats in Surabaya, and this problem was also faced by the processing business of goats themselves where there are obstacles in flowing their livestock and the benefits they get stagnant. Valenta as a goat breeder, a processed goat processing unit (processed food) and goat traders are aware of this. Through Valenta in-depth interviews, the actual business process of the activities and business processes carried out by Valenta can optimize its added value through existing goat processed products.

In line with this research, the purpose of this study is to provide value chain recommendations in the form of processed products to potential actors or actors who are already in this industry, and to do value added mapping that is only limited to the processing industry. From the value chain analysis in the previous section, it was found that in the goat commodity, there were several alternatives to add to the production process to the sales process, which can increase the added value of the goats.

After mapping the added value of the existing goat value chain, the next step is to do a value chain recommendation mapping, where the purpose of the implementation of value chain recommendations is to find out how to increase the value of goat commodity by creating new processed products. The new processed products are able to increase profitability and business effectiveness of industry players in this goat commodity like Valenta and can also bring new small, medium and large scales of industries to improve the welfare of the people of Surabaya and their surrounding areas. The recommendations given are observations from processed products outside Surabaya and inside Surabaya, each of which has its own selling value and market share.
From the observations made, goats can be processed from meat, skin, to waste. Mapping of the value chain recommendations is shown in Figure 5 where the processed goat products with blue lines are products that can be found in Surabaya. Of the many downstream products from processed goats, almost all types of processed table foods can be found in Surabaya, while for processed foods, currently processed meat goat products that can be found in Surabaya are goat sausages, and more products from goat milk and its derivatives such as goat cheese, goat yogurt, kefir goat, goat sinom and mask can be found in Surabaya.

For further recommendation of processed products, goat skin can be processed into leather jackets, souvenirs or crafts, and skin crackers, and processed meat products obtained include goat sausages, goat burgers, goat meatballs, shredded goats, goat jerky, and kebabs goats. Some references are taken from the products on the market, and the processing of goat milk, generally it has been done by Valenta processing units, includes goat cheese, goat yogurt, goat kefir, masks, but Valenta's processed milk is milk goat. Waste from goats can also be processed into organic fertilizer which is commonly known as manure and also feed ingredients for pellets. The recommendations of processed products are expected to provide an overview and reference to business actors and prospective actors interested in this goat processing industry.

The process of identification and selection of processed goat products in the value chain analysis was taken from two priority processed products, namely, dairy products and processed sausage products. Value chain analysis is able to find out what activities, businesses and valueadded products can be produced from goat commodity. In the value chain analysis, there is little information on processed products circulation in Surabaya; however, there are opportunities and potentials to become pioneers of processing companies both in MSMEs and Indonesian scales. The processed products circulating in Surabaya today are goat sausages and goat milk, and these goat dairy products are still by-products, namely, cheese, yoghurt, kefir and kefir goat masks. In addition to the value chain also, value chain mapping of various processed goat products and actors involved in these can be obtained. 


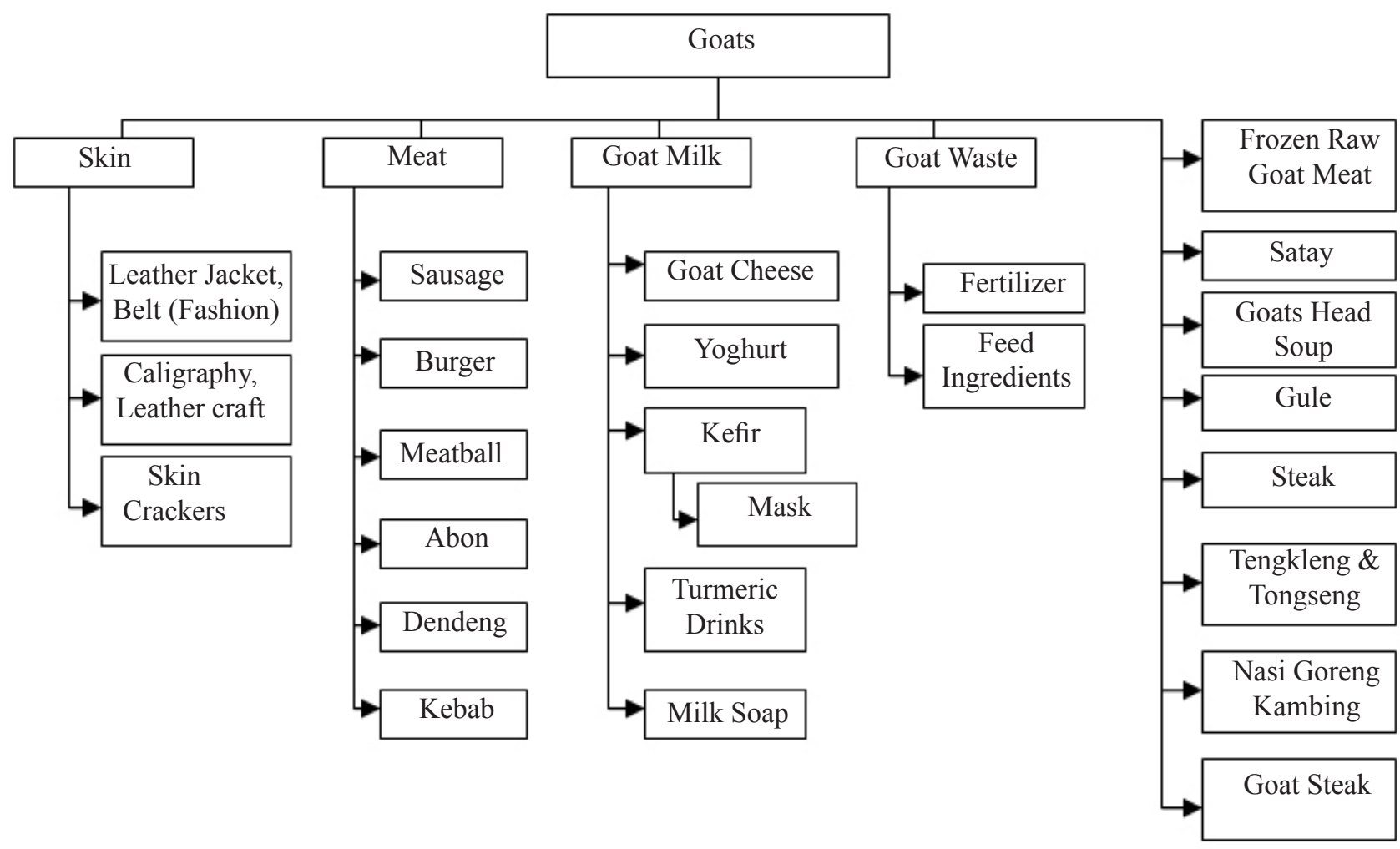

Figure 5. Recommended value chain mapping of goat processed products in Surabaya

\section{Managerial Implications}

What can be done by producers or parties who want marketing goat processed products to penetrate the market against sausage and milk products? Based on the data, the products of chicken or beef are mostly processed into chicken sausage and beef sausage, and there is cow milk product as well. The priority of selected goat processed products by consumers are sausages and goat milk too. This can be done by producers of processed goats so that consumers can slowly accept the goat products and can increase awareness of processed products from the goats. The use of these two processed products can be one of the validation tools of products if the producers intend to market new processed products such as goat sausage, goat burgers, and other processed products.

\section{CONCLUSIONS AND RECOMMENDATIONS}

\section{Conclusions}

There is information from the value chain analysis that there are a number of processed products currently circulating in Surabaya. The business actors engaged in the goat processed products recommend value chains produce 17 processed goat products, so it is expected that these products can increase the value-added to the product processed goats and can increase buyer interest in processed goat products.

\section{Recommendations}

The results of the Value Chain recommendation can be used by business actors who are currently doing a goat processing business and intending to diversify their goat products. Also, for farmers that want to spread their wings in the goat processing downstream business, or new companies in small or medium scale, or for those who want to produce goat processed products, it is expected that the mapping becomes a tool to help them, and it also becomes a reference for policy decision-making of business actors who are engaged in goat commodities so that the sale values of the goats increase.

On the other hand, this research could be the references to conduct a feasibility study of each recommendation product based on the results of the recommendation value chain. It is expected that the feasibility study will be able to provide an overview on which processed products are feasible to be marketed, in addition to suggestions for further research. In addition, it is hoped 
that processed products that have been recommended can be used as reference materials, and for further research, it is suggested that value chain analysis adds the $\mathrm{R} / \mathrm{C}$ ratio as a quantitative measurement tool in the value added section.

\section{REFERENCES}

AHDB. 2015. R\&D Review 2015. UK: Agriculture and Horticulture Development Board.

[ACIAR] Australian Centre for International Agricultural Research. 2012. Membuat Rantai Nilai Lebih Berpihak pada Kaum Miskin: Buku Pegangan bagi Praktisi Analisis Rantai Nilai edisi Terjemahan. Jakarta: Tabros.

Dwikurnia W. 2014. Rantai nilai (Value chain) komoditas cabai merah (Capsicum annuum) di Kabupaten Temanggung [thesis]. Semarang: Fakultas Ekonomika dan Bisnis Universitas Diponegoro.

Endiyani. 2014. Preferensi konsumen dan analisis rantai nilai produk olahan cabai merah kering (Studi Kasus: Wilayah Bogor) [thesis]. Bogor. Sekolah Pascasarjana. Institut Pertanian Bogor.

Humphrey J, Schmitz H. 2002. Developing country firms in the world economy: Governance and upgrading in global value chains. INEF Report, No. 61, University of Duisburg, Duisburg.

Inounu IB. 2005. Pemantapan Produktivitas dan Seleksi Domba Komposit Garut. Kumpulan Hasil-hasil penelitian APBN, Buku 1 Ruminansia. Bogor: Balai Penelitian Bogor.

Kaplinsky R, Morris M. 2002. A handbook for value chain research, IDRC. McCormick, D. \& Schmitz, H www.ids.ac.uk/ids/glo bal/wiego. html. [7 August 2018].

Kaplinsky R, Readman J. 2001. How can SME Producers Serve Global Markets and Sustain Income Growth?. Brighton: University of Brighton and University of Sussex.

[Kementan] Kementrian Pertanian. 2015. Renstra Kementerian Pertanian 2014-2018. Jakarta: Sekertariat Jenderal Kementerian Pertanian.
Kresnawati, I. 2013. Value chain analysis untuk perancangan rekomendasi kebijakan industri perikanan di Kota Tarakan dengan menggunakan sistem dinamik [thesis]. Surabaya: Institut Teknologi Sepuluh Nopember.

Kusumawardani MH. 2012. Membuat Rantai Nilai Lebih Berpihak pada Kaum Miskin. Canberra: Aciar.gov.au

Mahmilia F. 2007. Penampilan Reproduksi Kambing Induk: Boer dan Kacang yang disilangkan dengan Pejantan Boer. Seminar Nasional Teknologi Peternakan dan Veteriner 2007 page: 485-490.

Porter EM. 1985. Competitive Advantage-Creating and Sustaining Superior Performance. New York: Free Press.

Randolph TF et al. 2007. Role of livestock in human nutrition and health for poverty reduction in developing countries. Journal of Animal Science 85(11): 2788-2800. https://doi.org/10.2527/ jas.2007-0467.

Rudy T, Abubakar, Usmiati S. 2011. Diversifikasi Produk Olahan Ternak Ruminansia Kecil Melalui Teknologi Pasca Panen Mendukung PSDSK 2014. Bogor: Balai Besar Litbang Pascapanen Pertanian.

Tiven N, Suryanto E, Rusman. 2007. Komposisi kimia, sifat fisik dan organoleptik bakso daging kambing dengan bahan pengental yang berbeda. Agritech 27(1): 1-6. https://doi.org/10.22146/ agritech.9486.

WoodA. 2001.Value chains: an economist's perspective. IDS Bulletin, special issue: The Value of Value Chains 32(3): 41- 45. https://doi.org/10.1111/ j.1759-5436.2001.mp32003005.x.

Yusuf M. 2007. Kajian pemasaran dan pengembangan value added product dengan pemanfaatan rajungan menjadi produk olahan [thesis]. Semarang: Universitas Diponegoro.

Yusdja Y. 2004. Prospek Usaha Peternakan Kambing Menuju Tahun 2020. Prosiding Lokakarya Nasional Kambing Potong, Bogor: Pusat Penelitian dan Pengembangan Pertanian. page 21-27. 